\title{
PEWARISAN HARTA DI MINANGKABAU DALAM PERSPEKTIF KOMPILASI HUKUM ISLAM
}

\author{
Adeb Davega Prasna \\ Universitas Islam Negeri Syarif Hidayatullah Jakarta \\ JI. Ir. H. Juanda No. 95 Ciputat, Tanggerang Selatan 15412 \\ Email: adeb.davega@uinjkt.ac.id
}

Abstract: Inheritance of Property in Minangkabau in The Perspective of Islamic Law Compilation. The results of this study indicate there are several similarities and differences between the inheritance of property in Minangkabau Tradition and Compilation of Islamic Law. The similarity lies in the concept of inheritance of low treasures, namely that lower heirlooms include inheritance in the Compilation of Islamic Law because it is owned by Milk alRaqabah, the next equation is inheritance with collective system, it is contained in the Compilation of Islamic Law Article 183 and article 189 , and the last is the issue of grant, where the grant contained in Minangkabau tradition is actually a grant contained in Islamic law (fiqh). While the difference is in high treasures, where the high heirloom cannot be classified to the inheritance.. So it can be concluded that the system of inheritance of property in Minangkabau tradition does not conflict with Islamic law.

Keywords: Heritage Treasure, Low Treasure, Collective.

Abstrak: Pewarisan Harta Di Minangkabau Dalam Perspektif Kompilasi Hukum Islam. Hasil penelitian ini menunjukkan bahwa antara pewarisan harta dalam Adat Minangkabau dan Kompilasi Hukum Islam terdapat beberapa persamaan dan perbedaan. Persamaannya terdapat pada konsep pewarisan harta pusaka rendah, yaitu bahwa pusaka rendah termasuk harta warisan dalam Kompilasi Hukum Islam karena ia dimiliki secara Milk alRaqabah, persamaannya selanjutnya pada pewarisan dengan sistem kolektif, hal ini terdapat dalam Kompilasi Hukum Islam Pasal 183 dan pasal 189, dan terakhir adalah permasalahan hibah, dimana hibah yang terdapat dalam adat Minangkabau sejatinya adalah hibah yang terdapat dalam hukum Islam (fiqh). Sedangkan perbedaannya terdapat pada harta pusaka tinggi, yang mana pusaka tinggi tidak bisa digolongkan kepada harta warisan. Jadi bisa disimpulkan bahwa sistem pewarisan harta dalam adat Minangkabau tidak bertentangan dengan hukum Islam.

Kata Kunci: Harta Pusaka Tinggi, Harta Pusaka Rendah, Kolektif 


\section{Pendahuluan}

Pada dasarnya masyarakat Minangkabau adalah masyarakat yang menganut agama Islam. Masyarakat Minangkabau dilingkupi oleh dua kekuatan secara simultan, yaitu adat dan agama. Kedua kekuatan ini mempunyai tata nilai yang disebut hukum yang menuntut dari masyarakat Minangkabau itu loyalitas yang tinggi, yaitu patuh kepada agama sebagai seorang muslim dan patuh kepada adat sebagai masyarakat Minangkabau. Hal inilah yang merupakan makna dari falsafah hidup masyarakat Minangkabau, yaitu Adat Basandi Syarak, Syarak Basandi Kitabullah'. Bahwa hukum adat yang ada harus tunduk kepada Syariat, yaitu hukum Islam yang bersumber kepada Alquran dan Sunnah sebagai Kitabullah.

Untuk itu setiap aturan yang ada dalam masyarakat Minangkabau harus sesuai dengan Syariat Islam, kemudian aturan tersebut diundangkan melalui hukum Adat. Setiap aturan adat tidak boleh menyimpang dari syariat Islam, termasuk juga dalam hukum waris. Selain waris harus mengikuti ketentuan adat, juga harus sejalan dengan hukum waris dalam syariat Islam yang dalam hal ini adalah Hukum Waris Islam (Faraidh).

Sepintas ketentuan kewarisan dalam adat Minangkabau tampak berbeda dengan ketentuan kewarisan dalam Islam, terlebih dalam warisan harta pusaka tinggi ${ }^{2}$. Pertama, tentang hakikat kewarisan itu sendiri. Secara umum kewarisan itu adalah peralihan harta dari yang telah meninggal kepada ahli waris yang masih hidup. Inilah kewarisan yang berlaku dalam Islam. Tetapi dalam adat Minangkabau kewarisan harta pusaka itu bukanlah peralihan kepemilikan harta dan pembagian harta dari orang yang telah meninggal dunia kepada yang hidup, melainkan peralihan fungsi

${ }^{1}$ Artinya : Adat bersendi (berdasar) Syariat, Syariat bersendi Kitabullah

2 Di Minangkabau secara umum ada dua macam harta, yaitu harta pusaka tinggi dan harta pusaka rendah. Yang dimaksud dengan harta pusaka tinggi adalah harta yang dapat dari tembilang besi, dan pusako rendah didapat dari tembilang emas. Tembilang besi maksudnya adalah harta yang diperoleh secara turun temurun dari orang-orang terdahulu. Adapun tembilang emas adalah harta yang berasal dari hasil usaha sendiri. Lihat: Hamka, Islam dan Adat Minangkabau, (Jakarta: Pustaka Panjimas: 1984), h. 96 
dan tanggung jawab pengelolaan, pengurusan dan pengawasan harta dari generasi yang sudah meninggal kepada generasi yang masih hidup3. Hal ini sesuai dengan pepatah Adat Minangkabau "Biriekbiriek turun ka samak, dari samak ka halaman. Dari Niniek turun ka mamak, dari mamak ka kamanakan4." Yang berarti bahwa harta pusaka dalam ketentuan adat Minangkabau diwariskan ke keturunan menurut garis keturunan ibu (matrilineal). Tetapi untuk pewarisan harta pencaharian tetap dibagi menurut hukum faraidh ${ }^{5}$.

Kedua, kewarisan adat Minangkabau dalam hal pemilikan harta, adat Minangkabau menganut asas kolektif atau komunal yang berarti kepemilikan bersama. Harta pusaka milik kaum secara bersamasama dan bukan milik orang secara perorangan. Sedangkan kewarisan Islam menganut asas individual6, artinya setiap orang berhak memilikinya secara perorangan tanpa terikat oleh orang lain. Ketiga, Islam menganut asas kewarisan bilateral, yaitu masing-masing dari keluarga (ayah dan ibu) atau dari keturunan laki-laki dan perempuan berhak menerima warisan dengan sebab-sebab yang telah ditentukan, yaitu kekerabatan, hubungan pernikahan dan wala ${ }^{7}$. Sedangkan dalam adat Minangkabau, tidak menganut asas bilateral, tetapi kewarisan yang mengenal ahli waris hanya dari keturunan ibu atau keturunan perempuan saja. Hal ini karena Minangkabau menganut sistem kekerabatan matrilineal ${ }^{8}$, yaitu keturunan yang diambil dari garis ibu.

Dengan adanya perbedaan tersebut akhirnya menimbulkan banyak persepsi dan teori tentang hukum waris di Minangkabau,

3 Idrus Hakimy Dt. Rajo Penghulu, Pokok-Pokok Pengetahuan Adat Alam Minangkabau, (Bandung: Remaja Rosdakarya, 1994) h. 117

${ }^{4}$ Amir MS, Pewarisan Harato Pusako Tinggi dan Pencaharian, (Jakarta: Citra Harta Prima, 2011), hal. 3

5 Idrus Hakimy Dt. Rajo Penghulu, Pokok-Pokok Pengetahuan Adat Alam Minangkabau, (Bandung: Remaja Rosdakarya, 1994) h, 117

6 Hazairin, Hukum Kewarisan Bilateral Menurut Qur"an dan Hadits, (Penerbit: Tintamas, Jakarta, 1982), hal. 16.

${ }^{7} \mathrm{Hal}$ ini dijelaskan oleh Wahbah Az-Zuhaili di dalam Kitabnya Al-Fiqh Al-Islami Wa Adillatubu, Juz 10 Bab VI tentang Warisan

8 Yaswirman, Hukum Keluarga: Karakteristik dan Prospek Doktrin Islam dan Adat dalam Masyarakat Matrilinela Minangkabau, (Jakarta: Rajawali Press, 2013), h. 115 
apalagi dalam pewarisan harta pusaka. Ada pendapat yang menyatakan bahwa pewarisan harta di Minangkabau bertolak belakang dengan hukum waris Islam. Diantara yang berpendapat seperti itu adalah Syekh Ahmad Khatib Al-Minangkabawy (Imam Masjidil Haram keturunan Minangkabau), seperti yang tertuang dalam kitab beliau yang di tulis di Mekah pada akhir abad ke XIX yang berjudul Al-Dai' al-Masmu' Fii Al-Raddi 'ala Al-Tawarisi al-Ikhwati wa Awadi Al-Akhawati ma'a Wujud al-Ushuli wa al-Furu'i (Dakwah yang Didengar tentang Penolakan Atas Pewarisan Saudara dan Anak Saudara disamping Ada Orang Tua dan Anak) ${ }^{9}$. Demikian juga pendapat yang disampaikan oleh Safrudin Halimy Kamaluddin ${ }^{10}$ yang menyatakan bahwa hukum adat Minangkabau mengenai kewarisan tidak bisa diterima oleh hukum Islam.

Pendapat kedua menyatakan bahwa pewarisan harta di Minangkabau tidak bertentangan dengan hukum Islam, tetapi sudah sesuai dengan ketentuan yang ada dalam Syariat. Pendapat ini disampaikan oleh Abdul Malik Karim Amrullah yang merupakan murid dari Ahmad Khatib Al-Minangkabawy. Beliau berpendapat bahwa pewarisan harta di Minangkabau tidak bertentangan dengan hukum Islam. Beliau mengatakan bahwa harta pusaka itu sama keadaannya dengan harta wakaf atau harta musabalah ${ }^{11}$ di zaman Umar ibn Khattab. Pendapat ini juga diikuti diantaranya oleh Sulaiman Ar-Rasuli (Pendiri Pondok Pesantren Tarbiyah Islamiah Canduang ) ${ }^{12}$. Pendapat yang sama dengan alasan yang berbeda juga disampaikan oleh Idrus Hakimy ${ }^{13}$ bahwa Minangkabau tidak mengenal kesatuan antara ayah dan ibu seperti dalam Islam,

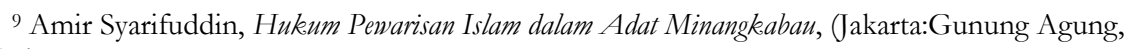
1984), h. 275

10 Safrudin Halimy Kamaluddin, Adat Minangkabau dalam Perspektif Hukum Islam, (Padang: Hayfa Press, 2005), h. 296

${ }^{11}$ Harta musabalah adalah harta kaum, atau harta milik suatu kelompok masyarakat. Harta musabalah ini awalnya muncul pada zaman Umar Bin Khattab, yaitu harta milik Suku Khaibar yang berasal dari harta rampasan perang

12 Amir Syarifuddin, Hukum Pewarisan Islam dalam Adat Minangkabau, (Jakarta:Gunung Agung, 1984), h. 278

13 Idrus Hakimy Dt. Rajo Penghulu, Rangkaian Mustika Adat Basandi Syarak di Minangkabau, hal. 208 
sehingga tidak bisa dikatakan bahwa Minangkabau melanggar sistem pewarisan Islam.

Pendapat ketiga adalah yang memisahkan antara harta pusaka dan harta pencaharian. Untuk harta pusaka diberlakukan hukum adat, yaitu diwarisi turun temurun secara kolektif menurut garis keturunan ibu (matrilineal). Sedangkan untuk harta pencaharian berlaku hukum waris Islam (Faraidh). Pendapat inilah yang dipakai dalam kongres Badan Permusyawaratan Alim Ulama, Niniak Mamak dan Cerdik Pandai Minangkabau pada tanggal 4 s/d 5 Mei 1952 di Bukittinggi, dan juga Seminar Hukum Adat Minangkabau yang diadakan di Padang pada tanggal 21 s/d 25 Juli 196814. Dan pendapat ini juga diperkuat oleh Buya Hamka, sebagaimana yang beliau jelaskan dalam bukunya yang berjudul "Ayahku"15.

Dengan kuatnya perbedaan pendapat yang terjadi di kalangan tokoh adat dan Ulama, maka banyak yang berkesimpulan bahwa pewarisan harta di Minangkabau memang tidak sesuai dengan hukum Islam. Malah muncul beberapa adagium yang menyatakan bahwa dalam masalah pewarisan harta pusaka di Minangkabau membelakangi hukum Islam karena dalam beberapa literatur kitab Fiqh tidak ditemukan sistem pewarisan harta secara kolektif dan sistem waris matrilineal sebagaimana yang dipraktekkan oleh masyarakat Minangkabau. Akan tetapi ketika kita mencoba melihat ketentuan tentang warisan yang terdapat dalam Kompilasi Hukum Islam (KHI) yang diundangkan pada tahun 1991 pada Buku II tentang Warisan, terdapat beberapa pasal yang boleh dikatakan cukup menarik. Karena ada beberapa ketentuan yang terdapat dalam Kompilasi Hukum Islam yang hampir tidak ditemukan dalam literatur kitab-kitab Fiqh klasik, seperti yang disampaikan oleh M. Amin Suma bahwa tidak semua isi Kompilasi Hukum Islam memuat hukum Islam apa adanya dan karenanya kurang tepat kalau Kompilasi Hukum Islam itu dinyatakan isinya melulu hukum

\footnotetext{
14 Amir MS, Pewarisan Harato Pusako Tinggi dan Pencaharian, Jakarta: Citra Harta Prima, 2011), h. 23

${ }^{15}$ Hamka, Ayahku, (Jakarta: Umminda, 1982), h. 13
} 
Islam $^{16}$. Di antara ketentuan yang dimaksud adalah Pasal 171, Pasal 183, Pasal 189, dan Pasal 211 tentang Kewarisan. Pasal-pasal tersebut sepintas mengandung unsur kemiripan dengan sistem pewarisan harta di Minangkabau dan menurut penulis bisa menjadi landasan pewarisan harta pusaka dalam masyarakat adat Minangkabau karena ada unsur persamaan dalam pasal-pasal tersebut dengan ketentuan warisan di Minangkabau.

\section{Pengertian Waris dalam Hukum Islam}

Kewarisan dalam Islam mengatur peralihan harta dari seseorang yang telah meninggal dunia kepada yang masih hidup. Aturan tentang peralihan harta ini disebut dengan berbagai nama, dalam literatur hukum Islam ditemui beberapa istilah untuk menamakan hukum kewarisan Islam, seperti Faraaidh, Figh al-Waris, dan Hukm alWaris ${ }^{17}$.

Faraaidh sendiri diartikan oleh Syekh Wahbah Al-Zuhaili18 sebagai masalah-masalah pembagian warisan. Sebab, faraaidh adalah bentuk jamak dari fariidhah, yang diambil dari kata fardhu yang berarti "penentuan", dan fariidhah bermakna "yang ditetapkan", karena di dalamnya ada bagian-bagian yang telah ditetapkan. Jadi AlFaraaidh menurut beliau adalah bagian-bagian yang telah ditentukan. Karena itu, kata al-faraaidh lebih banyak digunakan dalam menamai ilmu waris. Beliau melanjutkan bahwa pengkhususan istilah ini karena Allah Swt menamakannya dengan nama demikian. Hal ini sesuai dengan firman Allah,

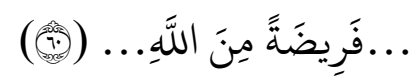

“...sebagai suatu ketetapan yang diwajibkan Allah..." (Qs. alTaubah [9]:60)

16 Muhammad Amin Suma, Keadilan Hukum Waris Islam: Dalam Pendekatan Teks dan Konteks, (Jakarta: Rajawali Press, 2013), h. 100

${ }^{17}$ Amir Syarifuddin, Hukum Kewarisan Islam, (Jakarta: Prenada Media, 2015), Edisi Kedua, h. 1 340

${ }^{18}$ Wahbah Al-Zuhaili, Fiqh al-Islami wa Adillatubu, (Damaskus: Daar al-Fikr, 2007) Juz 10, h. 
Sedangkan 'Ilmu Miraats adalah kaidah-kaidah fiqh dan perhitungan yang dengannya diketahui bagian setiap ahli waris dari peninggalan si mayit. Pengarang kitab al-Dur al-Mukhtaar wa Raad alMuhtaar sebagaimana dikutip oleh Syekh Wahbah al-Zuhaili menjelaskan ilmu miraats adalah ilmu tentang pokok-pokok fiqh dan hisab yang memberi pengertian tentang hak masing-masing ahli waris berupa peninggalan dan hak-hak mayit. ${ }^{19}$

Penggunaan kata mawaarits lebih melihat kepada objek waris, yaitu perihal harta yang beralih dari pewaris kepada ahli waris yang masih hidup. Sebab, kata mawaarits merupakan bentuk plural dari kata miraats yang berarti mauruts, "harta yang ditinggalkan". Dengan demikian, kata waarits lebih banyak digunakan merujuk kepada orang yang menerima harta warisan, karena waarits diartikan "dengan yang menerima warisan". ${ }^{20}$

Menurut Muhammad Ali al-Shabuni al-Miraats adalah berpindahnya hak kepemilikan dari seseorang yang meninggal dunia kepada ahli warisnya yang masih hidup, baik yang ditinggalkan itu berupa harta, atau tanah, atau apa saja yang berupa hak milik secara syar'i. ${ }^{21}$

Untuk hukum kewarisan sendiri secara terminologi dijelaskan oleh TM. Hasby al-Shiddieqy adalah ilmu yang apabila mempelajarinya dapat mengetahui berhak atau tidak berhak untuk mendapatkan warisan, serta ketentuannya yang berlaku bagi tiaptiap ahli waris dan penyelesaian pembagiannya. ${ }^{22}$

Sedangkan pada pasal 171 huruf a Kompilasi Hukum Islam (KHI) dijelaskan bahwa, "Hukum kewarisan adalah hukum yang mengatur tentang pemindahan hak kepemilikan harta peninggalan (tirkah) pewaris, menentukan siapa-siapa yang berhak menjadi ahli waris dan berapa bagiannya masing-masing".

19 al-Dur al-Mukhtaar wa Raad al-Mubtaar, sebagaimana dikutip Wahbah al-Zuhaili di dalam Figh Islami wa Adillatubu, (Damaskus: Daar al-Fikr, 2007), Juz 10, h. 340

${ }^{20}$ Amir Syarifuddin, Hukum Kewarisan Islam, h. 6

${ }^{21}$ Muhammad Ali al-Shabuni, Hukum Waris Dalam Islam, (Depok: Fathan Prima Media, 2013), h. 32

22 TM. Hasby al-Shiddieqy, Fiqhul Mawaris, (Jakarta: Bulan Bintang, 1973), h. 18 


\section{Asas-asas Hukum Kewarisan Islam}

Hukum kewarisan Islam atau yang dalam literatur hukum Islam biasa dengan faraaidh adalah salah satu bagian dari keseluruhan hukum Islam yang mengatur peralihan harta dari orang yang telah meninggal dunia kepada orang yang masih hidup.

Sebagai hukum Islam yang bersumber kepada Alquran dan Sunnah Nabi Muhammad Saw, hukum kewarisan Islam mengandung berbagai asas dan ketentuan. Di samping itu, hukum kewarisan Islam dalam hal tertentu mempunyai corak tersendiri, berbeda dengan hukum kewarisan lain. Berbagai asas hukum ini memperlihatkan bentuk karakteristik dari hukum kewarisan Islam itu.

Berikut ini akan dipaparkan beberapa mengenai asas-asas dalam hukum kewarisan Islam:

Pertama, Asas Ijbari. Dalam hukum Islam peralihan harta dari orang yang telah meninggal dunia kepada orang yang masih hidup berlaku dengan sendirinya tanpa usaha dari yang akan meninggal atau kehendak yang akan menerima. Cara peralihan harta seperti ini disebut secara ijbari $^{23}$. Kata ijbari yang berasal dari kata jabbar secara etimologis mengandung arti paksaan (compulsory), yaitu melakukan sesuatu di luar kehendak sendiri24. Hukum kewarisan Islam menjalankan asas ijbari berarti bahwa peralihan harta dari seseorang yang telah meninggal dunia kepada ahli warisnya berlaku dengan sendirinya menurut kehendak Allah tanpa tergantung kepada kehendak pewaris atau ahli waris. Unsur paksaan sesuai dengan arti terminologis tersebut terlihat dari segi bahwa ahli waris terpaksa menerima kenyataan pindahnya harta pewaris kepadanya sesuai dengan jumlah yang telah ditentukan. Unsur ijbari dalam kewarisan ini dapat dilihat dari firman Allah dalam surah al-Nisaa' ayat 7.

\footnotetext{
23 Amir Syarifuddin, Hukum Kewarisan Islam, h. 21-22

24 Amir Syarifuddin, Pelaksanaan Hukum Kewarisan Islam dalam Lingkungan Adat Minangkabau, (Jakarta: Gunung Agung, 1982), h. 18
} 
Kedua, Asas Bilateral. Asas bilateral dalam hukum kewarisan berarti bahwa seseorang menerima hak kewarisan dari kedua belah pihak garis kerabat, yaitu pihak kerabat garis keturunan laki-laki dan pihak kerabat garis keturunan perempuan. Asas ini secara nyata dapat dilihat dari firman Allah dalam surat al-Nisaa'[4] ayat 7, 11, 12, dan 176.

Ketiga, Asas Individual. Hukum Islam mengajarkan asas kewarisan secara individual, dengan arti bahwa harta warisan dapat dibagi-bagi untuk dimiliki secara perorangan. Keseluruhan harta warisan dinyatakan dalam nilai tertentu yang mungkin dibagi-bagi, kemudian jumlah tersebut dibagikan kepada setiap ahli waris yang berhak menurut kadar bagian masing-masing. Setiap ahli waris berhak atas bagian yang didapatnya tanpa terikat kepada ahli waris yang lain. Hal ini didasarkan kepada ketentuan bahwa setiap insan sebagai pribadi mempunyai kemampuan untuk menerima hak dan menjalankan kewajiban, atau dalam istilah ushul fiqh disebut dengan ahliyah al-wujub 25 .

Keempat, Asas Keadilan Berimbang. Asas keadilan berimbang dalam kewarisan menjelaskan bahwa baik laki-laki maupun perempuan sama-sama berhak tampil sebagai ahli waris, mewarisi harta peninggalan yang ditinggalkan oleh pewaris ${ }^{26}$. Sedangkan menurut Amir Syarifuddin27, asas keadilan berimbang dalam kewarisan dapat diartikan dengan keseimbangan antara hak dan kewajiban dan keseimbangan antara yang diperoleh dengan keperluan dan kegunaan. Atas dasar pengertian itulah terlihat asas keadilan dalam pembagian harta warisan dalam hukum Islam.

Secara mendasar dapat dikatakan bahwa perbedaan gender tidak menentukan hak kewarisan dalam Islam. Artinya, sebagaimana lakilaki, perempuan pun memiliki hak yang sama kuat untuk mendapatkan warisan. Hal ini secara jelas disebutkan dalam Alquran

\footnotetext{
25 Amir Syarifuddin, Hukum Kewarisan Islam, h. 25-26

26 Muhammad Daud Ali, Hukum Islam: Pengantar Ilmu Hukum dan Tata Hukum Islam di Indonesia, Jakarta: Rajawali Press, 2011), h. 142

27 Amir Syarifuddin, Hukum Kewarisan Islam, h. 28
} 
surah Al-Nisaa' ayat 7 yang menyamakan kedudukan laki-laki dan perempuan dalam hak mendapatkan warisan. Pada ayat 11, 12, dan 176 surah Al-Nisaa' secara terperinci diterangkan kesamaan kekuatan hak menerima warisan antara laki-laki dan perempuan, ayah dan ibu (ayat 11), suami dan isteri (ayat 12), serta saudara laki-laki dan perempuan (ayat 12 dan 176) 28 .

Kelima, Asas semata akibat kematian, Asas semata akibat kematian berarti peralihan peninggalan atau harta seseorang kepada orang lain dengan status kewarisan berlaku sesudah meninggalnya pewaris $^{29}$. Asas ini berarti bahwa harta seseorang tidak dapat beralih kepada orang lain dengan sistem waris selama pemilik harta masih hidup. Juga berarti bahwa segala bentuk peralihan harta seseorang yang masih hidup baik secara langsung maupun setelah dia meninggal dunia tidak termasuk ke dalam istilah warisan dalam sistem hukum Islam.

\section{Unsur-Unsur Kewarisan Islam}

Ada beberapa unsur atau rukun yang ada dalam sistem kewarisan Islam, diantaranya adalah : Pewaris, orang yang mewarisi (warits) dan harta warisan

Pewaris dalam literatur fiqh disebut dengan al-muwarrits, yaitu orang mati yang meninggalkan harta atau hak ${ }^{30}$. Atau bisa juga dikatakan seseorang yang telah meninggal dunia dan meninggalkan sesuatu yang dapat beralih kepada keluarganya yang masih hidup ${ }^{31}$. Berdasarkan prinsip bahwa peralihan harta dari pewaris kepada ahli waris berlaku ketika telah wafatnya pewaris, maka kata "pewaris" itu tepat diartikan seseorang yang telah wafat/meninggal dunia.

Ketentuan tentang pewaris ini harus terpenuhi syaratnya, yaitu telah jelas bahwa dia (pewaris) telah meninggal dunia, baik yang

\footnotetext{
28 Amir Syarifuddin, Hukum Kewarisan Islam, h. 28-29

${ }^{29}$ Muhammad Daud Ali, Hukum Islam, h. 143

30 Wahbah al-Zuhaili, Fiqh al-Islami Wa Adillatubu, h. 346

31 Amir Syarifuddin, Hukum Kewarisan Islam, h. 212
} 
meninggal dunia secara hakiki, atau meninggal dunia secara hukmi, atau meninggal dunia berdasarkan putusan hakim karena alasan tertentu ${ }^{32}$. Hal ini harus diketahui secara pasti, karena bagaimanapun keadaannya, manusia yang masih hidup tetap dianggap mampu untuk mengendalikan seluruh harta miliknya. Hak kepemilikannya tidak dapat diganggu gugat oleh siapa pun, kecuali setelah ia meninggal dunia ${ }^{33}$. Menganggap seseorang masih hidup selama belum ada kepastian tentang kematiannya, di kalangan ahli ushul fiqh disebut "mengamalkan prinsip istishab al-siffah".

Rukun waris yang kedua adalah orang yang mewarisi (warits), yaitu orang yang berhak mendapatkan warisan karena sebab-sebab tertentu ${ }^{34}$. Ada beberapa persyaratan mengenai seseorang yang akan menerima warisan secara hukum, yaitu : (a)Ahli waris itu telah atau masih hidup pada waktu meninggalnya pewaris( b)Tidak ada hal-hal yang menghalanginya secara hukum untuk menerima warisan (c) Tidak terhijab atau tertutup secara penuh oleh ahli waris yang lebih dekat.

Harta warisan atau yang dalam ilmu fiqh disebut dengan almauruts, adalah "peninggalan". Al-Mauruts dinamakan juga miraats dan irts, yaitu harta yang ditinggalkan oleh orang yang mewariskan atau hak-hak yang mungkin diwariskan ${ }^{35}$. Amir Syarifuddin membedakan antara harta warisan dengan harta peninggalan. Harta peninggalan adalah semua yang ditinggalkan oleh si mayit atau dalam arti apa-apa yang ada pada seseorang saat kematiannya, sedangkan harta warisan adalah harta peninggalan yang secara hukum syara' berhak diterima oleh ahli warisnya ${ }^{36}$.

32 Dalam Fiqh, kriteria seseorang meninggal dunia/mati itu terbagi tiga. Mati secara hakiki, mati secara hukmi dan mati secara taqdiri. Mati secara hakiki yaitu meninggal secara wajar, sedangkan mati secara hukmi, yaitu seseorang yang meninggal duniakarena dipersangkakan secara yuridis oleh suatu lembaga hukum legal. Adapun mati secara taqdiri dapat dipahami sebagai kematian seseorang atas persangkaan yang dianggap pasti dengan segala kecendrungan kepastian kebenarannya. Lihat Sukris Sarmadi, Hukum Waris Islam di Indonesia, (Yogyakarta: Aswaja Pressindo, 2013), h. 40-42.

${ }^{33}$ Muhammad Ali al-Shabuni, Hukum Waris Dalam Islam, h. 39

34 Wahbah al-Zuhaili, Fiqh al-Islami wa Adillatubu, h. 346

35 Wahbah al-Zuhaili, Fiqh al-Islami wa Adillatubu, h. 346

36 Amir Syarifuddin, Hukum Kewarisan Islam, h. 212 


\section{Harta dan Pewarisannya di Minangkabau}

Secara umum klasifikasi harta di Minangkabau ada dua jenis, yaitu Harta Pusako Tinggi dan Harta Pusako Randah ${ }^{37}$.

Harta Pusako Tinggi sesuai dengan penjelasan LKAAM (Lembaga Kerapatan Adat Alam Minangkabau) adalah harta kaum yang diterima secara turun temurun dari ninik ke mamak, dari mamak kepada kemenakan menurut garis keturunan ibu ${ }^{38}$. Harta pusako tinggi menurut M. Rasjid Manggis adalah hutan tinggi yang sekarang disebut juga "ulayat". Termasuk ke dalam harta pusaka tinggi ini adalah hutan dan padang, gunung dan bukit, danau dan tasik, rawa dan paya, serta lembah dan sungai ${ }^{39}$.

Sedangkan menurut Hamka, pusako tinggi adalah harta pusaka yang di dapat dari tembilang besi, dan pusako rendah di dapat dari tembilang emas ${ }^{40}$. Tembilang besi maksudnya adalah harta yang diperoleh secara turun temurun dari orang-orang terdahulu. Adapun tembilang emas adalah harta yang berasal dari hasil usaha sendiri. Selain itu ada juga yang menyebutnya dengan harta bersama, artinya harta yang diperoleh selama hidup berumah tangga.

Pewarisan harta pusako tinggi ini sesuai dengan ketentuan waris adat Minangkabau, yaitu diwariskan secara kolektif menurut garis keturunan ibu (matrilineal). Harta pusaka tinggi tidak boleh dijual dan digadaikan untuk kepentingan pribadi atau untuk beberapa orang41. Hak penggunaan harta pusaka dilaksanakan di rumah gadang oleh kaum ibu. Dalam setiap musyawarah kaum, suku dan nagari, kaum ibu sangat berpengaruh dalam menentukan. Berarti kaum ibu

37 Pembahasan harta di Minangkabau ini ada berbagai versi, ada yang membagi lima jenis, yaitu harta pusako tinggi, harta pusako randah, harta pancaharian, harta suarang, dan harta syarikat. Tetapi secara umum pembagian harta di Minangkabau hanya dua, yaitu harta pusako tinggi dan harta pusako randah.

38 LKAAM Sumatera Barat, Adat Basandi Syarak, Syarak Basandi Kitabullab; Pedoman Hidup Banagari, h, 68

39 M. Rasjid Manggis, Minangkabau; Sejarah Ringkas dan Adatnya, h. 202

${ }^{40}$ Hamka, Islam dan Adat Minangkabau, (Jakarta: Pustaka Panjimas: 1984), h. 96

41 Hanya saja, dalam kondisi tertentu pusaka tinggi dapat digadaikan berdasarkan kesepakatan anggota kaum dan ketika itu memang tidak ada biaya lain yang bisa digunakan selain harta pusaka tinggi tersebut. Kondisi tersebut adalah; ketika rumah gadang memerlukan renovasi, pernikahan kemanakan perempuan, penyelenggaraan jenazah, dan upacara penghulu baru. 
dapat mengetahui dan mempertahankan hak-hak yang diperoleh atas harta pusaka.

Sedangkan Harta Pusako Randah adalah segala harta yang didapat dari hasil usaha pekerjaan sendiri, termasuk di dalamnya adalah harta pencaharian suami isteri. Yaswirman menambahkan bahwa apabila ahli waris tetap menjaga keutuhan dari harta pusaka rendah ini dengan tidak dijual atau dibagi-bagi, lalu pada waktunya diwariskan kepada generasi berikut secara terus menerus sehingga sulit menelusurinya, maka ia beralih menjadi harta pusaka tinggi ${ }^{42}$.

Jadi ada kalanya harta pusaka tinggi juga berasal dari harta pusaka rendah yang dimanfaatkan secara turun-temurun, asal usulnya tidak dipersoalkan lagi. Sekali ia diwariskan secara adat, maka ia menjadi harta pusaka tinggi. Inilah yang banyak terjadi di tengah-tengah masyarakat adat Minangkabau sekarang. Demikian juga yang dipaparkan oleh Hamka bahwa pusaka rendah dapat menjadi pusaka tinggi, sedangkan pusaka tinggi tidak dapat menjadi pusaka rendah, kecuali bila adat tidak berdiri lagi. Hamka mengatakan "faraidh tidak dapat masuk kemari"43. Karena pada dasarnya harta pusaka tinggi tidak dapat dibagi-bagi, tetapi diwariskan secara turun temurun kepada anak kaum (suku) tersebut. Kaum hanya dapat mengambil manfaat dan hasil saja dari harta tersebut.

Harta pusaka rendah yang merupakan hasil pencaharian suami isteri diwariskan kepada anak sesuai dengan ketentuan syarak, yaitu hukum faraaidh. Kongres Tungku Sajarangan yang dilangsungkan pada tahun 1952 sepakat mengatakan bahwa harta pusaka tinggi jatuh ke kemenakan, sedangkan harta pusaka rendah diwariskan menurut hukum faraidh ${ }^{44}$. Akan tetapi, untuk harta pusaka rendah yang tidak dibagi dan sudah menjadi harta pusaka tinggi maka

\footnotetext{
42 Yawirman, Hukum Keluarga...., h. 155

${ }^{43}$ Hamka, Islam dan Adat Minangkeabau, h. 96

44 LKAAM Sumatera Barat, Adat Basandi Syarak, Syarak Basandi Kitabullab; Pedoman Hidup Banagari, h. 70
} 
diwariskan menurut ketentuan pewarisan harta pusaka tinggi, yaitu kepada kemenakan menurut sistem matrilineal.

\section{Sistem dan Asas Kewarisan Harta di Minangkabau}

Menurut Hazairin, secara garis besar ada tiga sistem kewarisan yang dipakai di Indonesia ${ }^{45}$, yaitu :

Pertama, sistem kewarisan individual, yaitu sistem kewarisan yang membagi-bagi harta peninggalan kepada orang perorangan sebagai ahli waris dan dibagi sama rata antar ahli waris. Sistem kekerabatan ini antara lain ditemukan pada masyarakat Jawa yang menganut kekerabatan bilateral dan Batak yang menganut patrilineal.

Kedua, sistem kewarisan mayorat, yaitu sistem kewarisan tunggal anak yang tertua dalam satu keluarga terhadap harta peninggalan atau sejumlah harta pokok dari keluarga tersebut. Kewarisan ini seperti yang terjadi pada masyarakat Sumatera Selatan dan Bali.

Ketiga, sistem kewarisan kolektif, yaitu sistem kewarisan secara kelembagaan. Kelembagaan yang dimaksud adalah keluarga sebagai satu kesatuan kekerabatan genealogis. Warisan ini biasanya berupa benda atau tanah sebagai lahan pertanian. Yang dibagi-bagi adalah giliran menggarap dan menikmati hasilnya. Penerima waris biasanya perempuan, laki-laki hanya boleh memungut hasilnya. Karena itu ia disebut harta pusaka sebagaimana yang terdapat di Minangkabu.

Jadi dari ketiga sistem kewarisan tersebut, yang dipakai di dalam adat Minangkabau adalah sistem kewarisan kolektif atau kelembagaan, dimana yang berhak menerima warisan adalah keluarga di dalam satu kaum menurut garis matrilineal, bukan perorangan.

Setelah agama Islam masuk dan berkembang di Minangkabau, maka secara berangsur pula Islam dapat mempengaruhi sistem

\footnotetext{
${ }^{45}$ Hazairin, Hukum Kewarisan Bilateral Menurut al-Qur'an dan Hadits, (Jakarta: Tintamas, 1982), h. 15
} 
kepemilikan harta dan sistem warisan di Minangkabau ini. Maka sistem waris pun di Minangkabau terbagi atas dua sistem sesuai dengan jenis hartanya. Untuk harta pusaka tinggi berlaku sistem warisan kolektif, sedangkan untuk harta pusaka rendah dan pencaharian berlaku sistem waris Islam dengan asas ijbari, bilateral, individual, keadilan berimbang, dan semata akibat kematian.

Sedangkan untuk asas kewarisan sendiri, Minangkabau juga mempunyai beberapa asas tertentu dalam kewarisan. Asas-asas itu banyak bersandar pada sistem kekerabatan dan kehartabendaan, karena hukum kewarisan di Minangkabau ditentukan oleh struktur kemasyarakatan. Adat Minangkabau mempunyai pengertian sendiri tentang keluarga dan cara perkawinan. Dari kedua itu maka muncullah ciri khas struktur kekerabatan dalam adat Minangkabau yang juga menimbulkan bentuk hukum kewarisannya.

Amir Syarifuddin menjelaskan ada 3 asas pokok dalam hukum kewarisan Adat Minangkabau ${ }^{46}$, yaitu : (a) Asas unilateral, yaitu hak kewarisan hanya berlaku dalam satu garis kekerabatan, yaitu kekerabatan melalui jalur ibu (matrilineal). Harta pusaka dari atas diterima dari nenek moyang melalui garis ibu dan ke bawah diteruskan kepada anak cucu melalui anak perempuan.(b) Asas kolektif, yaitu bahwa yang berhak atas harta pusaka bukanlah orang perorang, tetapi suatu kelompok secara bersama-sama. Berdasarkan hal ini, maka harta pusaka tidak dibagi-bagi, melainkan diwariskan secara kolektif. (c) Asas keutamaan, yaitu bahwa dalam penerimaan harta pusaka atau penerimaan dalam peranan untuk mengurus harta pusaka, terdapat tingkatan-tingkatan hak yang menyebabkan satu pihak lebih berhak dibandingkan dengan pihak yang lain, dan selama yang berhak masih ada maka yang lain belum dapat menerima.

46 Amir Syarifuddin, Pelaksanaan Hukum Kewarisan Islam dalam Lingkungan Adat Minangkabau, h. $231-236$ 


\section{Hibah dalam Adat Minangkabau}

Dalam sistem perekonomiannya, adat Minangkabau juga mengenal hibah atau pemberian. Lembaga hibah ini berkembang di Minangkabau setelah Islam masuk. Hibah sendiri dalam adat Minangkabau ada tiga macam, diantaranya adalah Hibah Laleh, Hibah Bakeh, dan Hibah Pampeh.

Hibah Laleh adalah pemberian dari sesorang kepada orang lain untuk selama-lamanya ${ }^{47}$. Sifatnya adalah tetap dan dimiliki selamalamanya oleh orang yang menerima hibah tersebut dan tidak dapat diganggu gugat oleh pihak manapun. Hibah ini bisa dari ayah kepada anak, dari mamak kepada kemenakan, dari bako kepada anak pisang dan sebagainya. Syarat hibah laleh ini baru bisa dilaksanakan apabila telah ada kesepakatan para ahli waris, baik ahli waris bertali darah, maupun ahli waris bertali adat. Hibah Bakeh adalah pemberian dari seorang bapak kepada anak, tetapi dengan persetujuan kemenakan $^{48}$. Harta yang dihibahkan ini hanya seumur anak tersebut, ketika sang anak meninggal, maka harta tersebut kembali menjadi milik kemenakan tanpa ada syarat. Sedangkan Hibah Pampeh adalah pemberian dari seorang mamak kepada anaknya atau orang dengan syarat yang menerima hibah memberikan pampeh (tebusan) kepada pihak mamak dan suatu saat kemenakan boleh mengambil kembali harta tersebut dengan mengembalikan tebusan tersebut ${ }^{49}$.

Jadi dapat disimpulkan bahwa dalam adat Minangakabu konsep warisan yang berlaku adalah kewarisan kelembagaan atau kolektif, dimana suatu harta diturunkan kepada keturunan dalam garis matrilineal secara kolektif yang bisa dimanfaatkan oleh seluruh anggota kaum. Setelah perkembangan Islam, barulah adat Minangkabau mengalami perubahan dalam sistem kewarisannya, yaitu berlakunya faraaidh terhadap harta pusaka rendah.

47 Idrus Hakimy Dt. Rajo Penghulu, Pokok-Pokok Pengetabuan Adat Alam Minangkabau, h.

48 Idrus Hakimy Dt. Rajo Penghulu, Pokok-Pokok Pengetabuan Adat Alam Minangkabau, h. 127

${ }^{49}$ M.S Dt. Rajo Penghulu, Orang Cerdik Pandai Minangkabau, h. 125 


\section{Konsep Harta Warisan dalam Adat Minangkabau dan Kompilasi Hukum Islam}

Mengenai konsep harta warisan sendiri yang ada dalam adat Minangkabau dan Kompilasi Hukum Islam terdapat beberapa persamaan dan perbedaan, dimana persamaan dan perbedaan tersebut akan memberikan kejelasan tentang kedudukan harta warisan adat Minangkabau menurut ketentuan yang terdapat dalam Kompilasi Hukum Islam.

Pertama, apabila kita lihat dari segi sumber harta warisan, maka terdapat perbedaan yang mendasar sumber harta yang terdapat dalam adat Minangkabau dengan Kompilasi Hukum Islam. Dalam adat Minangkabau sumber harta warisan ada dua, yaitu yang diperoleh secara turun temurun dari nenek moyang, dan yang diperoleh dari hasil pencaharian sendiri. Sedangkan dalam Kompilasi Hukum Islam, sumber harta warisan berasal dari harta bawaan si pewaris dan harta gono gini (harta bersama) yang diperoleh ketika hidup berumah tangga setelah menikah.

Kedua, apabila kita lihat dari jenis harta warisan, dalam adat Minangkabau harta warisan terbagi dua jenis. Pertama yaitu harta warisan pusaka tinggi yang sumbernya diperoleh dari turun temurun dan sifatnya tidak dimiliki utuh oleh seseorang, melainkan dimiliki oleh semua orang dalam satu kaum. Kedua harta warisan pusaka rendah yang sumbernya dari hasil pencaharian/usaha sendiri dan dimiliki utuh oleh orang yang mengusahakan tersebut. Sedangkan dalam Kompilasi Hukum Islam, harta jenis harta warisan adalah harta yang dimiliki utuh oleh si pewaris baik yang bersumber dari harta bawaan maupun yang berasal dari harta gono gini (harta bersama). Inilah yang dijelaskan dalam Kompilasi Hukum Islam pasal 171 huruf e.

Sebagaimana kita ketahui bahwa dalam konsep faraaidh, syarat harta yang bisa diwariskan oleh si pewaris kepada ahli warisnya adalah harta yang dimiliki secara Milk al-Raqabah atau Milk al-Taam, yaitu "harta yang dimiliki sendiri secara utuh zat sekaligus 
manfaatnya dan si pemilik tersebut bebas dalam penguasaannya"50. Makanya dalam pasal 171 huruf e Kompilasi Hukum Islam dijelaskan bahwa syarat harta warisan adalah harta tersebut telah bersih dari pembayaran hutang, biaya penyelenggaraan jenazah dan pemberian wasiat. Hal ini berarti bahwa suatu harta tidak bisa diwariskan apabila masih terdapat hak orang lain terhadap harta tersebut, atau harta tersebut tidak bisa diwariskan selama belum dimiliki secara utuh oleh si pewaris (Milkal-Raqabah).

Ketika konsep ini kita gunakan untuk membahas harta warisan dalam adat Minangkabau, maka harta pusaka tinggi bukanlah harta warisan, karena harta pusaka tinggi bukan milik perorangan, melainkan harta yang dimiliki secara bersama oleh suatu kaum, dan manfaatnya juga dimiliki secara bersama oleh suatu kaum tersebut, dengan kata lain bahwa bahwa harta pusaka tinggi bukanlah harta yang dimiliki secara Milk al-Raqabah atau Milk al-Taam. Seorang mamak hanya berhak atas pemeliharaan terhadap pusaka tinggi, demikian juga kemenakan perempuan dari jalur ibu hanya berhak atas manfaat dari harta pusaka tinggi tersebut, tanpa bisa memilikinya. Hal ini terlihat dari ketidak bolehan harta pusaka tinggi tersebut dijual, digadai maupun diwariskan secara perorangan tanpa persetujuan semua anggota kaum.

Sehingga untuk harta pusaka tinggi dalam adat Minangkabau tidak bisa digunakan konsep warisan Islam, karena ia bukanlah harta warisan sebagaimana terdapat dalam faraaidh dan Kompilasi Hukum Islam. Maka, keberadaan harta pusaka tinggi dibiarkan abadi sebagaimana ketentuannya, yaitu pengelolaan dan manfaatnya diwariskan secara kolektif menurut jalur matrilineal.

${ }^{50}$ Dalam kajian fiqh al-Mu'amalah, milik terbagi tiga, yaitu Milk al-Raqabah atau Milk alTaam, Milk, al-Manfa'ah, dan Milk al-Irtifaq. Milk al-Raqabah atau Milk al-Taam adalah kepemilikan terhadap zat dari sesuatu sekaligus manfaatnya, dimana si pemilik memiliki seluruh hak yang disyariatkan. Milk al-Manfa'ah adalah yaitu kepemilikan seseorang terhadap benda atau barang terbatas kepada pemanfaatannya saja, tidak dibenarkan secara hukum untuk menguasai harta itu. Sedangkan Milk al-Irtifaq adalah hak menggunakan dan memanfaatkan suatu barang karena demi kepentingan barang yang lain, seperti hak atas air irigasi, hak kanal atau saluran air, hak lewat, dan sebagainya. (Lihat Wahbah al-Zuhaili, Figh al-Islami wa Adillatubu, h. 267) 
Sedangkan harta pusaka rendah adalah harta yang merupakan hasil pencaharian seseorang yang dia miliki secara utuh dan sempurna, dan dia punya kuasa penuh terhadap harta tersebut, sehingga konsep pewarisannya harus mengikuti faraaidh dan Kompilasi Hukum Islam. Hal ini juga sudah menjadi kesepakatan bersama pemuka adat dan agama di Minangkabau setelah deklarasi Bukik Marapalam di awal abad 19.

Jadi bisa kita simpulkan bahwa konsep harta warisan dalam adat Minangkabau dengan Kompilasi Hukum Islam memiliki persamaan dan perbedaan. Persamaannya adalah bahwa harta pusaka rendah merupakan warisan sebagaimana dijelaskan Pasal 171 huruf e Kompilasi Hukum Islam yang dimiliki secara utuh oleh pewaris, maka pewarisannya sama-sama menggunakan konsep faraaidh. Sedangkan perbedaannya terdapat pada harta pusaka tinggi, yang merupakan bukan harta warisan sebagaimana Pasal 171 huruf e Kompilasi Hukum Islam, karena dia tidak dimiliki secara utuh oleh perorangan dalam suatu kaum. Maka pewarisannya tidak menggunakan konsep faraaidh, melainkan menggunakan konsep yang ada dan berlaku dalam masyarakat adat Minangkabau selama ini, yaitu diwariskan secara kolektif kepada kemenakan menurut jalur keibuan (matrilineal).

\section{Asas Kolektif dalam Hukum Waris Adat Minangkabau dan Asas Perdamaian dalam Pasal 183 dan Pasal 189 Kompilasi Hukum Islam}

Seperti yang telah dijelaskan sebelumnya bahwa pewarisan harta pusaka tinggi dalam adat Minangkabau tidak menggunakan konsep waris Islam, karena harta pusaka tinggi bukanlah harta warisan sebagaimana yang terdapat dalam Kompilasi Hukum Islam. Sedangkan untuk harta pusaka rendah, harus diwariskan sesuai dengan konsep faraaidh, yaitu bagian anak laki-laki dua kali bagian anak perempuan. 
Akan tetapi pada sebagian masyarakat Minangkabau, mereka tidak mewariskan harta pusaka rendah yang dimiliki secara faraaidh, melainkan diwariskan secara kolektif untuk dimiliki secara bersama oleh seluruh anggota kaum, dan pewarisan seperti ini sudah berjalan lama dalam masyarakat Minangkabau dengan persetujuan ahli waris. Hal ini terlihat dari tidak adanya penolakan anak laki-laki terhadap tindakan orang tuanya yang mewariskan harta pusaka rendah kepada anak perempuan untuk dimiliki bersama secara kolektif oleh anggota kaum menurut garis matrilineal. Hal ini juga yang dijelaskan dalam "Lokakarya Penyamaan Persepsi Adat Basandi Syarak, Syarak Basandi Kitabullah" pada tanggal 6 Februari 2002 di Padang, bahwa untuk pusaka rendah walaupun sudah diberlakukan faraaidh, tapi tidak tertutup kemungkinan pembagiannya menurut kesepakatan ahli waris atau orang yang berhak menerimanya, berdasarkan kesepakatan ini maka harta pusaka rendah tersebut dijadikan kepunyaan bersama dan dijadikan milik paruik, atau milik jurai, atau milik lundang bak durian (milik keluarga waris matrilineal terdekat) 51 .

Pewarisan kolektif dengan dasar kesepakatan ini menurut penulis memiliki unsur-unsur kesamaan dengan asas perdamaian yang terdapat di dalam Pasal 183 dan asas kolektif yang terdapat dalam Pasal 189 Buku II Kompilasi Hukum Islam.

Dalam melakukan analisis ini, penulis mengutip pendapat dari Sukris Sarmadi yang menjelaskan sebagai berikut : Ada dua dasar alasan yang memungkinkan bagi KHI untuk membolehkan terjadinya pembagian dengan cara perdamaian, sebagai berikut : Pertama, Para ahli waris telah mengetahui bagian saham mereka masing-masing secara hukum materil Islam. Apabila perdamaian pembagian terjadi pastilah didasarkan atas pertimbangan tertentu yang komitmen terhadap kondisi hubungan kekeluargaan seperti; salah satu pihak dari ahli waris mendapatkan saham yang lebih sedikit dari para ahli waris lainnya, padahal ahli waris yang

51 LKAAM Sumatera Barat, Adat Basandi Syarak, Syarak Basandi Kitabullab; Pedoman Hidup Banagari, h. 71. Demikian juga dijelaskan oleh Prof. Dr. Yaswirman. (Lihat Yaswirman, Hukum Keluarga...., h. 155) 
dimaksud tergolong orang yang memerlukan terhadap harta waris; dan juga harta waris yang akan dibagi merupakan sumber perekonomian keluarga, bukan hanya menyangkut kehidupan para ahli waris tetapi juga kerabat lain yang tida berhak atas harta warisan. Kedua, Berdasarkan fiqh waris Islam, sebagian besar ulama faradhiyun membolehkan terjadinya takharuj berupa perjanjian yang diadakan ahli waris mengundurkan dirinya dari menerima saham bagian warisan sebagai pergantian. Berdasarkan dua alasan di atas, perdamaian merupakan salah satu cara praktik pembagian harta warisan ${ }^{52}$.

Hal senada juga disampaikan oleh Abdurrahman ${ }^{53}$ dalam menjelaskan Pasal 183 Kompilasi Hukum Islam, bahwa dimungkinkan adanya prinsip musyawarah di dalam pembagian harta warisan.

Demikian juga dijelaskan oleh Suhairi tentang perdamaian dalam pembagian harta warisan, berikut penulis sampaikan ringkasan tulisan beliau yang diterbitkan oleh Jurnal Al-Manahij :

Dalam pengertian khusus kesepakatan seluruh ahli waris untuk keluarnya seorang atau lebih dari ahli waris dari pembagian warisan. Cara begini dalam literature hukum Islam disebut takharuj atau tasaluh. Takharuj atau tasaluh adalah suatu perjanjian yang diadakan oleh para ahli waris untuk mengundurkan (mengeluarkan) seorang ahli waris dalam menerima bagian warisan dengan memberikan suatu prestasi, baik prestasi tersebut berasal dari harta milik orang yang mengundurkannya, maupun berasal dari harta warisan yang bakal dibagi-bagikan. Dasar yang dipakai oleh ulama yang membenarkan takharuj ini adalah kerelaan dan kesepakatan pihak yang berhak menerimanya. Para ahli waris adalah orang yang berhak menerima harta tersebut, hingga dapat bertindak atas hartanya sesuai dengan kemauan dan kerelaannya. Di samping itu, ulama yang membolehkan takharuj juga mendasarkan kepada atsar shahabi (perbuatan para sahabat Nabi) dari Abu Yusuf dari Amru ibn Dinar yang berasal dari

\footnotetext{
52 Sukris Sarmadi, Hukum Waris Islam di Indonesia (Yogyakarta: Aswaja Pressindo, 2013), h. $33-36$

53 Abdurrahman, Kompilasi Hukum Islam di Indonesia, h. 80
} 
Ibnu 'Abbas bahwa seorang janda 'Abdul Rahman ibn 'Auf bernama Tumadir mengadakan persetujuan dengan tiga orang dari janda suami lainnya untuk keluar dari kelompok penerima warisan suaminya dengan imbalan yang diterimanya sebanyak delapan puluh tiga dirham. Muhammad Abu Zahrah dalam karyanya Ushul Figh menegaskan bahwa hak seseorang untuk mewarisi harta peninggalan ahli warisnya yang meninggal dunia termasuk ke dalam kategori hak hamba atau hak perorangan secara murni. Berdasarkan keterangan Abu Zahrah tersebut, pembagian harta warisan, bilamana setiap pihak ahli waris secara sukarela membaginya secara kekeluargaan, bisa dibagi secara kekeluargaan atau secara damai sesuai dengan kesepakatan setiap pihak yang terkait. Bahkan berdasarkan hal tersebut, adalah sah bilamana ada di antara ahli waris yang merelakan atau menggugurkan haknya dalam pembagian harta warisan itu untuk diserahkan kepada ahli waris lain. Dalam konteks ini, penulis dapat menyatakan bahwa ketentuan pembagian warisan yang ditentukan nash (baik Al-Qur'an maupun as-Sunnah) adalah merupakan hukum yang mengatur, bukan hukum yang mengikat. Para ahli waris dapat melakukan perdamaian berdasarkan kesepakatan dan kerelaan masing-masing dalam pembagian harta warisan, dengan catatan adanya kesepakatan, kerelaan semua pihak. Jika ada sebagian atau salah satu ahli waris yang tidak menyetujuinya maka pembagiannya harus dikembalikan sesuai dengan ketentuan hukum kewarisan Islam $^{54}$.

Muhammad 'Ali al-Shabuni menyebut cara penyelesaian dengan al-Takharaj min al-Tarikah, yaitu pengunduran diri seorang ahli waris dari hak yang dimilikinya untuk mendapatkan bagian secara syar'i dalam hal ini dia hanya meminta imbalan berupa sejumlah uang atau barang tertentu dari seorang ahli waris lainnya ataupun dari harta peninggalan yang ada55. Demikian juga yang disampaikan oleh Ahmad Rofiq dengan mengutip nasehat Umar ibn Khattab sebagaimana diungkapkan oleh Muhammad Salam Madkur.

\footnotetext{
54 Suhairi, Perdamaian dalam Pembagian Harta Warisan; Kritik atas Konsep Qat'i dalam Hukum Kewarisan IslamI, al-Manahij VI, no.1 (t.tt, Januari 2012): h. 152

55 Muhammad 'Ali ash-Shabuni, Pembagian Warisan menurut Islam, h. 141
} 
Berdasarkan beberapa teori dan penjelasan di atas, maka penulis berkesimpulan bahwa dimungkinkan adanya perdamaian dalam pembagian harta warisan, dan inilah yang terdapat di dalam Kompilasi Hukum Islam pasal 183.

Masyarakat Minangkabau adalah masyarakat yang memahami dan tunduk kepada syariat Islam. Falsafah adat yang berbunyi "Adat Basandi Syarak, Syarak Basandi Kitabullah" membuktikan bahwa hukum adat Minangkabau tunduk kepada hukum Islam, walaupun Islam masuk ke Minangkabau belakangan setelah tatanan adat itu lahir. Tetapi dengan masuknya Islam diadopsi oleh masyarakat Minangkabau dan dijadikan pegangan tertinggi dalam kehidupan, termasuk dalam persoalan hukum dan adat. Apalagi setelah deklarasi Bukit Marapalam di awal abad 19 yang melibatkan semua unsur dalam masyarakat Minangkabau semakin memperkuat bahwa hukum adat Minangkabau tunduk kepada hukum Islam. Oleh karena itu, tidak mungkin hukum adat Minangkabau membelakangi hukum Islam, termasuk dalam persoalan pewarisan.

Sistem waris kolektif yang selama ini banyak dipermasalahkan karena dianggap bertentangan dengan prinsip waris Islam dengan teori baku 2:1 menurut penulis adalah keliru. Karena sebagaimana yang telah dipaparkan sebelumnya bahwa memungkinkan adanya perdamaian dalam pembagian harta warisan, apalagi sudah dicantumkan dalam Kompilasi Hukum Islam pasal 183. Perdamaian dalam pembagian harta warisan sebagaimana dimaksud Kompilasi Hukum Islam tersebut sebenarnya sama dengan sistem kolektif dalam waris adat Minangkabau.

Diantara unsur kesamaan antara asas perdamaian dengan asas kolektif dalam pewarisan harta Minangkabau menurut penulis adalah :

Pertama, Dalam pasal 183 Kompilasi Hukum Islam dijelaskan bahwa para ahli waris dapat bersepakat melakukan perdamaian dalam pembagian harta warisan setelah masing-masing menyadari 
bagiannya. Pada masyarakat Minangkabau mereka menyadari bahwa jumlah bagian warisan antara antara ahli waris laki-laki dengan ahli waris perempuan itu adalah 2:1, tetapi sudah menjadi kesepakatan dan kebiasaan bagi mereka bahwa bagian anak laki-laki tidak dibagi, melainkan dibiarkan saja dan dijadikan sumber penghasilan rumah gadang yang akan digarap oleh anak perempuan dalam rangka mempersiapkan keturunan pewaris sako. Kalau kita mengkaji kembali tambo dan sejarah adat Minangkabau memang dapat diindikasikan bahwa yang pertama kali manaruko (bekerja) adalah pihak laki-laki, tetapi hasil dari manaruko tersebut diserahkan kepada keluarga yang perempuan untuk selanjutnya diwariskan secara kolektif menurut garis keturunan ibu, bukan kepada anaknya. Sistem seperti ini diterima oleh anak dari laki-laki yang manaruko tersebut dan tidak ada pertentangan dari mereka ${ }^{56}$. Demikian juga kalau kita lihat sebagian masyarakat Minangkabau yang mewariskan harta pusaka rendah yang mereka miliki kepada anak perempuan secara kolektif yang selanjutnya dimiliki bersama oleh anggota kaum, dan bahkan terkadang ditingkatkan statusnya menjadi harta pusaka tinggi. Tujuan dari waris kolektif ini adalah supaya keluarga yang satu kaum tersebut memiliki pusat mata pencaharian yang akan digunakan untuk menghidupi anak kemenakan, karena ketika suatu kaum tidak memiliki harta dan pusako maka kaum tersebut akan hilang dan punah, dan ketika ini terjadi pada semua kaum, maka adat Minangkabau pun akan hilang dan punah. Jadi masyarakat Minangkabau bukannya tidak mengetahui kalau bagian ahli waris laki-laki adalah 2:1 dengan perempuan, tetapi mereka sudah menyerahkan secara damai bagian mereka kepada ahli waris perempuan dengan dasar kebiasaan yang ada dan untuk menjaga keutuhan kaum, dan hal ini sesuai dengan konsep perdamaian di dalam Pasal 183 Kompilasi Hukum Islam.

Kedua, Selanjutnya Pasal 189 Kompilasi Hukum Islam menjelaskan bahwa pembagian harta warisan yang berupa lahan

\footnotetext{
${ }^{56} \mathrm{Hal}$ ini sebagaimana dijelaskan oleh Yus Dt. Parpatiah dalam kaset rekaman "Pitaruah Ayah" yang dikeluarkan oleh Balerong Group Jakarta tentang "Konsultasi masalah Adat Miangkabau".
} 
pertanian yang luasnya kurang dari 2 hektar supaya dipertahankan kesatuannya sebagaimana semula, dan dimanfaatkan untuk kepentingan bersama para ahli waris yang bersangkutan ${ }^{57}$. Hal ini sudah sangat jelas dan sangat bersesuaian dengan waris kolektif dalam adat Minangkabau sebagaimana dijelaskan di atas.

Ketiga, Dasar dari perdamaian dalam Kompilasi Hukum Islam ini antara lain adalah untuk menjaga pusat perekonomian keluarga, karena ada kalanya pada sebagian kaum, harta warisan tersebut adalah pusat perekonomian keluarga yang kalau dibagi akan membawa dampak yang kurang baik bagi para ahli waris karena mereka akan kehilangan sumber perekonomian ${ }^{58}$. Ini jugalah yang menjadi alasan kenapa masyarakat adat Minangkabau itu memakai sistem waris kolektif pada sebahagian harta pusaka rendah yang mereka miliki, karena pusaka tinggi dan sebagian pusaka rendah milik kaum adalah sumber mata pencaharian untuk menghidupi kaum tersebut beserta anak kemenakan, sehingga dengan sistem waris kolektif ini akan menjaga keutuhan kaum tersebut dan akan menopang perekonomian keluarga serta menjamin kelangsungan hidup bersama dalam suatu kaum.

Pada dasarnya, alasan yang mendasar dalam pembagian warisan secara kolektif dengan perdamaian yang berlaku dalam adat Minangkabau dan Kompilasi hukum Islam ini adalah untuk menghindari dari kemiskinan dan kemelaratan salah satu pihak ahli waris sebagaimana firman Allah dalam Alquran surah al-Nisaa' ayat 9:

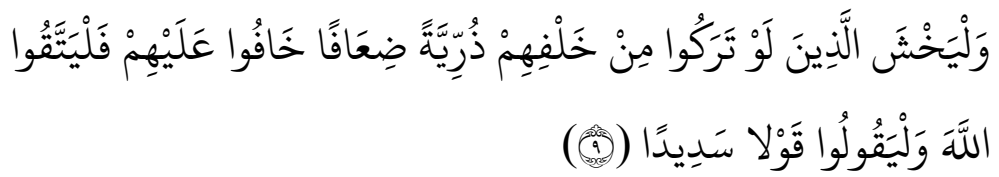

"Dan hendaklah takut kepada Allah orang-orang yang seandainya meninggalkan dibelakang mereka anak-anak yang lemah, yang mereka khawatir terhadap (kesejahteraan) mereka. Oleh sebab itu hendaklah

57 Pasal 189 Kompilasi Hukum Islam

58 Sukris Sarmadi, Hukum Waris Islam di Indonesia, h. 33-34 
mereka bertakwa kepada Allah dan hendaklah mereka mengucapkan perkataan yang benar." (Qs. al-Nisaa'[4]: 9)

Jadi, asas perdamaian yang ada di dalam Kompilasi Hukum Islam ini sebenarnya adalah asas kolektif yang selama ini dipraktekkan oleh masyarakat adat Minangkabau. Sehingga pewarisan harta di Minangkabau yang telah menjadi tradisi umum masyarakat ini sudah sesuai dan tidak bertentangan dengan hukum Islam, khususnya dengan Kompilasi Hukum Islam yang menjadi rujukan bagi masyarakat Indonesia, apalagi ketika kita menggunakan kaidah العادة المحكمة (adat yang dijadikan hukum).

\section{Konsep Hibah dalam Hukum Waris Adat Minangkabau dan Pasal 211 Kompilasi Hukum Islam}

Sebagaimana telah dijelaskan pada BAB III sebelumnya bahwa dalam adat Minangkabau juga melaksanakan sistem hibah terhadap harta. Konsep hibah yang terdapat dalam adat Minangkabau ini berlaku atas pemberian harta dari orang tua kepada anaknya, atau dari keluarga ayah kepada si anak, yang dalam sistem adat Minangkabau biasa disebut Hibah Bako ka Anak Pisang (Hibah/pemberian keluarga ayah kepada si anak) dengan syarat harus mendapat persetujuan semua ahli waris dalam kaum tersebut. Hibah tersebut ada yang bersifat tetap dan abadi untuk selamanya (Hibah Laleh), dan ada yang bersifat hanya untuk sementara dengan ketentuan yang berlaku (Hibah Bakeh dan Hibah Pampeh).

Sedangkan konsep hibah yang ada dalam fiqh adalah pemberian dari seseorang kepada orang lain ketika dia masih hidup atas dasar sesuatu dan lain hal. Hibah ini bisa saja dari orang tua kepada anak, antar saudara, kepada orang lain dan sebagainya. Sayyid Sabiq menjelaskan bahwa hibah dalam hukum Islam adalah penyerahan hak milik kepada orang lain semasa hidup yang mempunyai hak tanpa ada suatu imbalan ${ }^{59}$. Kemudian dalam kitab Fathul Qadir

${ }^{59}$ Sayyid Sabiq, Figh as-Sunnah, (Beirut: Dar Al-Fikr, 2008), Juz 3, h. 984 
sebagaimana dikutip oleh Amir Syarifuddin dijelaskan bahwa penyerahan yang dimaksud adalah upaya mengalihkan sesuatu kepada orang lain. Usaha pengalihan itu dibatasi oleh sifat-sifat yang menjelaskan hakikat dari hibah itu. Pertama, kata "hak milik" yang berarti bahwa yang diserahkan itu adalah materi dari harta, sehingga kalau yang diserahkan itu manfaatnya saja, perbuatan itu disebut pinjaman. Kata "selagi hidup" mengandung arti bahwa perbuatan pemindahan itu berlaku sewaktu yang punya hak masih hidup dan beralih hak itu secara efektif selama dia masih hidup, sedangkan "tanpa adanya imbalan" berarti bahwa perbuatan itu adalah sematamata kehendak sepihak dan tanpa mengharapkan apa-apa ${ }^{60}$.

Bila diperhatikan hakikat hibah sebagaimana dijelaskan di atas dan dibandingkan dengan pengertian hibah yang berlaku di lingkungan adat Minangkabau, maka akan terlihat jelas bahwa yang berlaku di Minangkabau selama ini adalah hibah yang terdapat dalam hukum Islam itu sendiri. Ini berarti bahwa hibah yang telah melembaga dalam lingkungan adat Minangkabau adalah pengaruh Islam, yang pelaksanaannya disesuaikan dengan keadaan yang berlaku di Minangkabau.

Untuk mengetahui sejauh mana penyesuaian hibah dalam adat Minangkabau dapat diketahui dari unsur pokok dan prinsip-prinsip hibah dalam hukum Islam. Diantara unsur pokok dari hibah serta syaratnya sebagaimana dijelaskan oleh Sayyid Sabiq adalah seperti berikut61: (1) Orang yang menghibahkan (Al-Wahib). Adapun syaratnya adalah cukup umur (baligh) ${ }^{62}$, pemilik harta yang akan dihibahkan, dapat bertindak sendiri, serta melakukan perbuatan itu atas kemauan sendiri (tidak dipaksa). Hal ini juga terdapat dalam pokok-pokok hibah di Minangkabau, dimana yang berhak memberikan hibah adalah si pemilik harta kalau harta tersebut adalah pusaka rendah, dan orang sekaum kalau harta tersebut adalah

${ }^{60}$ Amir Syarifuddin, Pelaksanaan Hukum Kewarisan Islam dalam Lingkungan Adat Minangkabau, h. $252-253$

${ }^{61}$ Sayyid Sabiq, Fiqh as-Sunnah, (Beirut: Dar Al-Fikr, 2008), Juz 3, h. 985-986

62 Ukuran baligh ini di dalam Kompilasi Hukum Islam pasal 210 ayat (1) adalah seseorang yang telah berusia sekurang-kurangnya 21 tahun. 
pusaka tinggi. (2) Orang yang diberi hibah (Al-Mauhub Lahu). Adapun syaratnya adalah hadir pada waktu akad hibah dilangsungkan. Hal ini juga sama dengan pokok hibah di Minangkabau, dimana dijelaskan bahwa hibah dilangsungkan dengan disaksikan orang yang diberi hibah beserta penghulunya63. (3) Barang yang dihibahkan (Al-Mauhub). Adapun syaratnya adalah barang yang nyata, bernilai serta dapat dimiliki. Sedangkan di dalam Kompilasi Hukum Islam ditambahkan bahwa barang yang dihibahkan tidak boleh melebihi $1 / 3$ bagian dari total jumlah harta yang dimiliki ${ }^{64}$. Demikian juga dalam adat Minangkabau, bahwa yang bisa diwariskan hanyalah harta (pusako), sedangkan sako tidak bisa dihibahkan. (4) Lafadz Ijab dan Qabul. Syaratnya adalah lafadz tersebut jelas dan sama-sama dipahami oleh kedua belah pihak.

Kemudian dalam Pasal 211 Kompilasi Hukum Islam ditambahkan mengenai hibah antara orang tua kepada anaknya. Dimana dalam Pasal ini diatur bahwa hibah dari orang tua kepada anak dapat dikategorikan sebagai sebuah warisan. Berdasarkan hal ini bisa dipahami bahwa ketika seorang ayah misalnya memberikan sejumlah harta baik berupa tanah atau harta lain kepada anakanaknya, maka pemberian itu bisa dianggap sebagai sebuah warisan dari orang tua kepada anak tersebut. Walaupun pelaksanaan hibah tersebut menurut A. Rofiq harus berdasarkan kesekapatan anakanaknya agar tidak terjadi perpecahan dalam keluarga ${ }^{65}$.

Bila diperhatikan adat Minangkabau sebelum adanya pengaruh Islam yang berhubungan dengan harta, terlihat ada beberapa prinsip. Pertama, bahwa seorang laki-laki hanya bertanggung jawab terhadap kehidupan kemenakannya yang sewaktu-waktu akan menggantikan perannya sebagai mamak dan pimpinan di kaumnya dalam sistem kekerabatan matrilineal. Kedua, bahwa harta tersebut adalah

${ }^{63}$ Amir Syarifuddin, Pelaksanaan Hukum Kewarisan Islam dalam Lingkungan Adat Minangkabau, h. 254

64 Pasal 210 ayat (1) Kompilasi Hukum Islam. Pembatasan 1/3 ini demi menjaga keberadaan ahli waris nantinya sehingga mereka tidak dirugikan. Manurut Sukris Sarmadi ada beberapa riwayat hadits yang tidak membolehkan hibah melebihi $1 / 3$, sebagaimana halnya dalam wasiat. (Lihat Sukris Sarmadi, Hukum Waris Islam di Indonesia, h. 143)

${ }^{65}$ A. Rofiq, Hukum Islam di Indonesia, h. 437-474 
kepunyaan kaum dan hanya dapat digunakan untuk kepentingan anggota kaum dan tidak dapat beralih keluar lingkungan kaum. Ketiga, bahwa ikatan batin seorang ayah di rumah anak dan istrinya sebagai seorang sumando (pendatang) sangat lemah, kehadiranya hanya untuk memperbanyak anggota keluarga si istri dan dia tidak punya kuasa sama sekali di rumah istrinya, dan anak-anaknya itu tidak dinisbatkan sukunya kepada ayahnya itu.

Atas dasar ketiga prinsip di atas, maka seorang laki-laki tidak merasa perlu untuk mengalihkan harta kaumnya kepada anakanaknya, karena anak-anaknya itu sendiri berada di bawah tanggun jawab mamaknya (saudara ibunya). Sehingga menurut Amir Syarifuddin pada waktu itu belum diperlukan adanya lembaga hibah yang akan mengoreksi sistem kewarisan yang berlaku'6. Ini membuktikan bahwa sebelum Islam masuk, Minangkabau belum mengenal lembaga hibah.

Lembaga hibah ini masuk ke Minangkabau seiring dengan kesadaran masyarakat Minangkabau yang telah memeluk agama Islam untuk bertanggung jawab secara moral dan materil terhadap anak-anaknya. Untuk itulah dia harus berusaha bagi kepentingan anak dan istrinya tersebut. Pengaruh hukum Islam yang mengharuskan seorang ayah bertanggung jawab terhadap anak dan istrinya, belum dapat mengalahkan tanggung jawab mamak kepada kemenakan, dan sekaligus juga tidak dapat merombak ketentuan harta pusaka dan pewarisannya, yang mungkin dilakukan hanyalah penyesuaian. Bentuk penyesuaian yang dilakukan adalah dengan memasukkan lembaga hibah ke dalam sistem hukum adat Minangkabau. Karena seorang laki-laki tidak dapat sama sekali mewariskan hartanya kepada anak-anaknya, maka cara yang dapat digunakan adalah menghibahkannya kepada anak-anaknya. Karena cara ini tidak merombak sistem hukum adat yang ada, maka cara

66 Amir Syarifuddin, Pelaksanaan Hukum Kewarisan Islam dalam Lingkungan Adat Minangkabau, 
inipun diterima secara adat dengan ketentuan yang berlaku sesuai hukum adat ${ }^{67}$.

Apa yang telah dikemukakan di atas terlihat pada beberapa kasus hibah harta pusaka tinggi dan pusaka rendah di Sumatera Barat sebagaimana yang dikutip oleh Amir Syarifuddin seperti kasus Mukhtar dengan keputusan di Raad van Justitie Padang R.V.J Padang tanggal 1 Desember 1927 dan kasus Abdullah Sidi Mangkuto di Pengadilan Negeri Padang Panjang Nomor Perd.2/9/1977, serta putusan Pengadilan Negeri Padang Panjang No. 11/1964 dan putusan Putusan Pengadilan Tinggi Padang tanggal 29 Maret 1975 No.Perd.61/1964/PTPD yang dikuatkan oleh Mahkamah Agung tanggal 22 Oktober 1975 No.1029 K/Sip/197568. Selanjutnya adalah putusan Pengadilan Negeri Padang Nomor 57/Pdt.G/2012/PN.Pdg Tahun 2012 mengenai hibah harta pusaka tinggi, putusan Pengadilan Tinggi Agama Padang Nomor 0024/Pdt.G/2013/PTA.Pdg Tahun 2013 tentang Hibah harta pencaharian dan putusan kasasi Mahkamah Agung Nomor $2887 \mathrm{~K} / \mathrm{Pdt} / 2012$. Hal ini membuktikan bahwa peralihan harta pusaka, baik pusaka tinggi maupun pusaka rendah dari seorang laki-laki kepada anaknya melalui hibah sudah diakui keberadaannya dan berlaku di dalam adat Minangkabau.

Jadi dapat diambil intisari bahwa konsep hibah yang terdapat dalam adat Minangkabau sesungguhnya adalah konsep hibah yang terdapat dalam hukum Islam itu sendiri, karena hibah yang ada tersebut adalah sebuah wujud produk dari perkembangan hukum Islam yang ada di Minangkabau untuk menyelaraskan prinsipprinsip hukum Islam dengan hukum adat tanpa merombak hukum adat yang telah ada.

67 Ketentuan yang dimaksud adalah persyaratan hibah dalam adat Minangkabau sebagaimana dijelaskan sebelumnya. Dan ketentuan ini berlaku untuk penghibahan harta pusaka tinggi, sedangkan untuk harta pusaka rendah dan harta pencaharian tidak berlaku. Karena setelah adanya pemisahan antara pusaka tinggi dengan pusaka rendah, maka harta pusaka rendah bukan lagi milik kaum, melainkan menjadi milik pribadi.

68 Amir Syarifuddin, Pelaksanaan Hukum Kewarisan Islam dalam Lingkungan Adat Minangkabau, h. $255-257$ 
Kemudian, kalau kita berpatokan kepada Kompilasi Hukum Islam pasal 211 yang menjelaskan bahwa hibah dari orang tua kepada anaknya dapat diperhitungkan sebagai warisan, maka bisa kita simpulkan bahwa pemberian harta berupa hibah yang diberikan oleh seorang ayah kepada anaknya atau hibah harta pusaka dari bako kepada anak pisang69 bisa dianggap sebagai sebuah bentuk warisan yang diakui keberadaannya dalam Kompilasi Hukum Islam.

Sehingga pewarisan harta di Minangkabau, baik harta pusaka tinggi maupun harta pusaka rendah dari aspek hibah memiliki kesamaan dengan prinsip hibah yang diperhitungkan sebagai warisan yang terdapat di dalam Kompilasi Hukum Islam pasal 211 tersebut. Karena seorang ayah bisa saja mewariskan harta pusaka miliknya kepada anaknya melalui hibah dengan dasar kesepakatan anggota kaum si ayah, dan hal itu merupakan sebuah bentuk dari kewarisan.

Dari beberapa penjelasan diatas terlihat bahwa berdasarkan studi analisis komparataif yang penulis lakukan terhadap hukum adat Minangkabau dengan Kompilasi Hukum Islam tentang kewarisan terdapat beberapa persamaan dan perbedaan antara keduanya. Sehingga terbantahkan pendapat yang selama mengatakan bahwa adat Minangkabau telah menyalahi hukum Islam dalam masalah kewarisan. Yang ada adalah dalam menjalankan sistem kewarisannya, adat Minangkabau telah sejalan dengan hukum Islam tanpa menghapuskan nilai-nilai adat itu sendiri, apalagi dalam persoalan pewarisan harta pusaka rendah atau harta pencaharian di Minangkabau yang memang sudah menerapkan sistem pewarisan hukum Islam (faraaidh).

Sedangkan untuk harta pusaka tinggi memang tidak diberlakukan sistem waris dalam faraaidh, karena harta pusaka tinggi sendiri bukanlah termasuk Milk al-Raqabah yang bisa dijadikan harta warisan menurut hukum Islam, sehingga tidak bisa dilekatkan

${ }^{69}$ Bako adalah sebutan untuk keluarga ayah, dan Anak Pisang adalah sebutan untuk si anak oleh Bako (keluarga ayah)-nya 
faraaidh kepadanya, kecuali seseorang menghibahkan harta pusaka tinggi milik kaumnya kepada anaknya atas persetujuan semua anggota kaum dengan niat sebagai mewariskannya dengan alasan bahwa keturunan kaum tersebut telah punah, maka hal ini bisa dianggap sebagai sebuah bentuk kewarisan berdasarkan pasal 211 Kompilasi Hukum Islam.

\section{Penutup}

Mengenai konsep harta, terdapat persamaan dan perbedaan antara warisan dalam ketentuan Kompilasi Hukum Islam dan adat Minangkabau. Persamaannya yaitu pada harta pusaka rendah, bahwa harta pusaka rendah termasuk ke dalam unsur harta warisan dalam Kompilasi Hukum Islam, sehingga pewarisannya menggunakan faraaidh. Sedangkan perbedaannya terdapat pada harta pusaka tinggi. Bahwa harta pusaka tinggi bukanlah termasuk harta warisan dalam Kompilasi Hukum Islam karena hak punya atas harta pusaka tinggi bukanlah Milk al-Raqabah, sehingga padanya tidak bisa diterapkan faraaidh.

Terkait dengan asas perdamaian terdapat persamaan antara Adat Miangkabau dan perdamaian dalam Kompilasi Hukum Islam pasal 183 dan pasal 189. Bahwa warisan koletif yang selama ini dipratekkan dalam masyarakat Minangakabau sejatinya adalah warisan dengan konsep perdamain dalam Pasal 183 dan warisan kolektif dalam Pasal 189 Kompilasi Hukum Islam.

Adapun tentang hibah kepada anak dapat dihitung sebagai warisan, juga terdapat persamaan antara Kompilasi Hukum Islam dan adat Minangkabau. Bahwa konsep hibah yang terdapat dalam adat Minangkabau sebenarnya merupakan hibah yang terdapat dalam hukum Islam, kemudian adat Minangabau juga mengenal hibah dari orang tua kepada anaknya yang dapat diperhitungkan sebagai harta warisan sebagaimana terdapat dalam Kompilasi Hukum Islam. 


\section{Pustaka Acuan}

al-Qur'an al-Karim

Abdurrahman. Kompilasi Hukum Islam di Indonesia. Jakarta: Akademika Pressindo, 1992.

Al-Asqalani, Ibnu Hajjar. Bulugh al-Maraam min Adillat al-Ahkaam. Beirut: Dar al-Kutb al-Islamiyah, 2002.

Al-Bukhari, Imam. Shahih Bukhari, Juz IV. Kairo: Daar wa Mathba' alSya'biy, t.t.

Al-Shabuni, Muhammad Ali. Hukum Waris Dalam Islam. Depok: Fathan Prima Media, 2013.

Al-Shiddieqy, TM. Hasby. Fiqhul Mawaris. Jakarta: Bulan Bintang, 1973.

Al-Zuhaili, Wahbah. Figh al-Islami wa Adillatuhu, Juz 10. Damaskus: Daar al-Fikr, 2007.

Ali, Muhammad Daud. Hukum Islam: Pengantar Ilmu Hukum dan Tata Hukum Islam di Indonesia. Jakarta: Rajawali Press, 2011.

Bakhtiar, Nurman Agus, dkk. Ranah Minang Ditengah Cengkeraman Kristenisasi. Jakarta: Bumi Aksara, 2005

Balitbang dan Diklat Kementerian Agama. Pelaksanaan Hukum Waris di Kalangan Umat Islam Indonesia. Jakarta: Maloho Abadi Press, 2010.

Bzn, B. Ter Haar. Asas-Asas dan Susunan Hukum Adat. Terj: Soebakti Poesponoto. Jakarta: Pradnya Paramita, 1980.

Dijk, Van. Pengantar Hukum Adat Indonesia. Terj: A. Soehardi. Bandung: Sumur, 1979.

Dirajo, Datuk Sangguno. Curaian Adat Alam Minangkabau. Bukittinggi: Pustaka Indonesia, 1987.

Hakimy, Idrus Dt. Rajo Penghulu. 1000 Pepatah-petitih, Mamang, Bidal, Pantun Gurindam Bidang Sosial Budaya, Ekonomi, Politik, Hukum, Hankam, dan Agama di Minangkabau. Bandung: Remaja Rosdakarya, 1994.

Pasambahan Adat di Minangkabau. Bandung: Remadja Karya, 1984. 
Pokok-Pokok Pengetahuan Adat Alam
Minangkabau.Bandung: Remaja Rosdakarya, 1994. Bandung: Remaja Rosdakarya, 1994.

Hamka. Ayahku. Jakarta: Umminda, 1982.

-----------,Islam dan Adat Minangkabau. Jakarta: Pustaka Panjimas, 1984.

Hazairin, Hukum Kewarisan Bilateral Menurut Qur"an dan Hadits. Penerbit: Tintamas, Jakarta, 1982.

Hidayati, Sri dan Alimin. Konsep Waris dalam Islam. Jakarta: Balitbang dan Diklat Kemenag RI, 2011.

Julius DT. Malako Nan Putiah. Mambangkik Batang Tarandam Dalam Upaya Mewariskan dan Melestarikan Adat Minangkabau Menghadapi Modernisasi Kehidupan Bangsa. Bandung: Citra Umbara, 2007.

Kemal, Iskandar. Beberapa Studi tentang Minangkabau. Padang: Fakultas Hukum dan Pengetahuan Masjarakat Universitas Andalas, 1971.

Khalifah, Muhammad Thaha Abu al-'Ula. Ahkam al-Mawarisi. Mesir: Dar al-Salam, 2011.

LKAAM Sumatera Barat. Adat Basandi Syarak, Syarak Basandi Kitabullah. Padang: Sako Batuah, 2002.

M.S, Amir. Adat Minangkabau; Pola dan Tujuan Hidup Orang Minang. Jakarta: Citra Harta Prima, 2011.

----------, Pewarisan Harato Pusako Tinggi dan Pencaharian. Jakarta: Citra Harta Prima, 2011.

M.S Dt. Rajo Penghulu. Orang Cerdik Pandai Minangkabau. Padang: Universitas Bung Hatta dan LKAAM Sumatera Barat, 1991.

Manggis, M. Rasjid. Minangkabau; Sejarah Ringkas dan Adatnya. Padang: Sridharma, 1971.

Mardani. Hukum Kewarisan Islam di Indonesia. Jakarta: Rajawali Press, 2015.

Marzuki, Peter Mahmud. Penelitian Hukum. Jakarta:Kencana Prenada Media, 2014. 
Muhibbin, Moh dan Abdul Wahid. Hukum Kewarisan Islam sebagai Pembaharuan Hukum Positif di Indonesia. Jakarta: Sinar Grafika, 2009.

Nasution, Amin Husein. Hukum Kewarisan; Suatu Analisis Komparatif Pemikiran Mujtahid dan Kompilasi Hukum Islam. Jakarta: Raja Grafindo Persada, 2012.

PPJM Fakultas Syariah dan Hukum UIN Syarif Hidayatullah Jakarta. Pedoman Penulisan Skripsi. Jakarta: PPJM Fakultas Syariah dan Hukum UIN Syarif Hidayatullah Jakarta, 2012

Rofiq, Ahmad. Hukum Islam di Indonesia. Jakarta: Rajawali Press, 2003. Sabiq, Sayyid. Fiqh as-Sunnah. Beirut: Dar Al-Fikr, 2008.

Safrudin Halimy Kamaluddin. Adat Minangkabau dalam Perspektif Hukum Islam. Padang: Hayfa Press, 2005.

Salihima, Syamsul Bahri. Perkembangan Pemikiran Pembagian Warisan dalam Hukum Islam dan Implementasinya pada Pengadilan Agama. Jakarta: Kencana Prenadamedia, 2016.

Salman, Otje. Kesadaran Hukum Masyarakat terhadap Hukum Waris. Bandung: Alumni, 1993.

Sarmadi, Sukris. Hukum Waris Islam di Indonesia (Perbandingan Kompilasi Hukum Islam dan Figh Sunni). Yogyakarta: Aswaja Pressindo, 2013.

Saydam, Gaozali. Kajian Adat dan Syarak Minangkabau. Padang: PPIM, 2004.

Soekanto, Soerjono dan Sri Mamudji. Penelitian Hukum Normatif (Suatu Tinjauan Singkat). Jakarta: Rajawali Press, 2001.

Suhairi, Perdamaian dalam Pembagian Harta Warisan; Kritik atas Konsep Qat'i dalam Hukum Kewarisan IslamI, al-Manahij VI, no.1 (t.tt, Januari 2012).

Suma, Muhammad Amin. Keadilan Hukum Waris Islam: Dalam Pendekatan Teks dan Konteks. Jakarta: Rajawali Press, 2013.

Syarifuddin, Amir. Hukum Kewarisan Islam, cet. II. Jakarta: Prenada Media, 2015. Jakarta:Gunung Agung, 1984. 
Yaswirman. Hukum Keluarga: Karakteristik dan Prospek Doktrin Islam dan Adat dalam Masyarakat Matrilinela Minangkabau. Jakarta: Rajawali Press, 2013.

Yusuf, A. Muri. Metode Penelitian; Kuantitatif, Kualitatif dan Penelitian Gabungan. Jakarta, Kencana Prenada Media, 2014. 